\title{
ESPAÇOS DE VIDA E MOBILIDADE DE MULHERES EM LIMEIRA: experiências urbanas do caminhar
}

\section{Ana Carolina Grilli Felizardo*, Eduardo Marandola Jr.}

\section{Resumo}

O presente trabalho tem como finalidade investigar a experiência de mulheres no contexto das novas mobilidades urbanas. Assim, nos permita compreender como as transformações sociais afetam as relações de gênero, os sentidos da mobilidade e, em sentido mais amplo, da própria cidade.

\section{Palavras-chave:}

Situação, habitar, deslocamentos a pé.

\section{Introdução}

Muito se tem discutido, recentemente, acerca da mudança do papel das mulheres na sociedade devido ao seu frequente ingresso no mercado de trabalho. Esse fator pode ser associado ao sistema patriarcal no qual estamos inseridos culturalmente, onde a mulher sempre foi vista como o outro, o objeto que sempre estará em condição de subordinação e compreende-se que seu papel é pertencer a família e nas funções domésticas e não para as ocupações públicas (BEAUVOIR, 2016).

Atualmente, as mulheres estão ocupando espaços e posições que antes eram ocupadas, predominantemente, por homens. Por conta destas transformações, as cidades se tornaram espaços onde o público feminino passou a apoderar-se e a ter maior visibilidade e com isso vem surgindo novos padrões de mobilidades. É de conhecimento geral que, o espaço urbano é ocupado, majoritariamente, por homens e pelo fato da cultura machista entrelaçada na nossa sociedade de que as mulheres deveriam pertencer aos lares, pode-se questionar se essas cidades foram construídas por homens para homens. Neste contexto, discutiremos o fato das mobilidades femininas e as vivências de medos nesses ambientes estarem atrelados a esse fator histórico.

Observar as experiências das mulheres no âmbito dessas novas mobilidades urbanas nos permitem entender as novas relações de gêneros e as circunstâncias que as cercam. Por esse fato, a pesquisa foi fundamentada a partir de relatos e experiências de mulheres no município de Limeira a partir de deslocamentos a pé.

\section{Resultados e Discussão}

Ao fazer uma análise dos deslocamentos das seis entrevistadas durante o trabalho de campo, pôde-se perceber alguns aspectos semelhantes nos relatos de cada uma, e como pesquisadora, eu pude sentir algumas das experiências que essas mulheres têm em seus deslocamentos. Marandola Jr faz uma relação do trabalho de campo com a experiência do fenômeno estudado, que traz a possibilidade de desenvolver empatia com as pessoas que compartilham suas experiências com a pesquisadora.

É de conhecimento geral que as cidades possuem características que causam tanto o afastamento das pessoas quanto o acolhimento. As mulheres, por exemplo, se deslocam por esse espaço com determinados obstáculos que os homens já não enfrentam, mesmo que violência seja uma questão que oferece risco à todos.

Porém, no caso das mulheres, vivenciam uma vulnerabilidade desigual no espaço urbano, todo orientado ao homem. As experiências dos homens e de mulheres nesses lugares são distintas (QUEIRÓS; MORGADO; COSTA; MILEU; ALMEIDA; VALE; 2019).

A pesquisa trouxe muitos relatos semelhantes de mulheres que buscam estratégias e táticas para lidar com a violência e a vulnerabilidade urbana sofridas no dia-a-dia. Existem espaços que repelem essas mulheres na cidade de Limeira e lugares que as acolhem. Neste sentido, o conhecimento espacial, sobretudo nos trajetos cotidianos, mas, sobretudo, no bairro de residência parece ser predominante para constituírem ambientes que as deixam confortáveis para se deslocar. Já terrenos baldios e lugares escuros traz uma certa exposição à violência.

\section{Conclusões}

Limeira, assim como outras cidades contemporâneas, não foi pensada para as mulheres ocuparem os espaços públicos. Há obstáculos estruturais a serem vencidos, o que pode ser objeto de políticas públicas específicas no sentido de tornar os deslocamentos e os espaços públicos acolhedores e seguros para as mulheres.

\section{Agradecimentos}

Agradeço à atenção de todos do Laboratório de Geografia dos Riscos e Resiliência, da paciência e dedicação do meu orientador Eduardo Marandola durante esse tempo de pesquisa, aos meus amigos e familiares presentes.

\section{Referências}

BEAUVOIR, Simone de. O segundo sexo. Tradução de Sergio Milliet. 3. ed. Rio de Janeiro, RJ: Nova Fronteira, 2016. 2 v.

MARANDOLA JR., Eduardo. Habitar em risco: mobilidade e vulnerabilidade na experiência metropolitana. 2008. 278p. Tese (Doutorado em Geografia) - Instituto de Geociências, Universidade Estadual de Campinas, Campinas

QUEIRÓS, Margarida; MORGADO, Paulo; COSTA, Nuno Marques da; MILEU, Nelson; ALMEIDA, Aníbal; VALE, Mário. Igualdade de Género nas Geografias EspácioTemporais: Uma Análise a partir de Dispositivos Móveis. Revista Latino Americana de Geografia e Gênero, v. 10, n. 1, p. 0325, 2019. 